\title{
Alternative animal model for studies of total skin thickness burns ${ }^{1}$
}

\author{
Ana Laura Martins de Andrade', Julia Risso Parisi", Patrícia Brassolatti"', Nivaldo Antonio Parizotto ${ }^{\text {IV }}$
}

'Fellow Master degree, Postgraduate Program in Physiotherapeutic Resources Laboratory, Universidade Federal de São Carlos (UFSCar), Brazil. Acquisition and interpretation of data, statistical analysis, manuscript writing.

"Fellow Master degree, Postgraduate Program in Biosciences, Universidade Federal de Alfenas (UNIFAL), Brazil. Intellectual and scientific content of the study.

I'PhD in Biotechnology, UFSCar, Sao Carlos-SP, Brazil. Intellectual and scientific content of the study.

IVFellow PhD degree, Postgraduate Program in Physiotherapeutic Resources Laboratory, UFSCar, Sao Carlos-SP, Brazil. Intellectual and scientific content of the study, technical procedures.

\begin{abstract}
Purpose: To present an alternative experimental model of third degree burn of easy reproducibility.

Methods: Eighteen male Wister rats were randomly divided into three groups, 6 of which were allocated to each group. A soldering iron coupled to an aluminum plate was used to produce burn, at a temperature of $150^{\circ} \mathrm{C}$, with different exposure times per group. Group 5 (G5) animals were burned at $150^{\circ} \mathrm{C}$ with exposure time of 5 seconds; Group 10 (G10) the animals were burned at $150^{\circ} \mathrm{C}$ with exposure time of 10 seconds and group 15 (G15) the animals were burned at $150^{\circ} \mathrm{C}$ with exposure time of 15 seconds.

Results: Histopathological analyzes showed that all three groups had similar morphological characteristics, with total thickness involvement.

Conclusion: The technique is effective to reproduce a third degree burn and suggests the temperature of $150^{\circ} \mathrm{C}$ with 5 seconds of exposure in order to minimize the risks to the animals.
\end{abstract}

Key words: Burns. Models, Animal. Skin. Rats. 


\section{Introduction}

Burns are tissue lesions that represent a severe form of trauma ${ }^{1}$. According to the World Health Organization, about 1.000,000 people are affected by burns each year in Brazil, and death records worldwide are close to $300,000^{2,3}$. Considering the high rate of morbidity and mortality associated with burns, in the last decade the number of researchers investigating innovative resources for burn treatment has increased, and a significant reduction in the number of deaths has already been observed in clinical care when such therapies are applied ${ }^{1,4,5}$.

Thus, in order to better explore the pathophysiology of burn and the healing process evolution through new treatment methods, the experimental model has been extensively used $^{5}$. The current literature describes several protocols to perform burn in an experimental model, such as those performed with soldering iron, but there are differences related to both the size of the lesion, temperature and time of exposure. With this, it is observed that the protocols are not yet well established for each degree of impairment to be induced, as some stipulate similar parameters for different degrees of burns ${ }^{5-7}$.

In this context, this study aimed to propose an experimental protocol, effective, for induction of specifically third-degree burns in rats. Therefore, it is expected that this protocol will serve as a reference for future studies aimed at the study of treatments for this type of injury.

\section{Methods}

The present study was developed in the Laboratory of Therapeutic Resources of the Universidade Federal de São Carlos (UFSCar) and was approved by the animal use Ethics Committee of the UFSCar, protocol no
6224231115. The animals used in the study remained throughout the experiment in the Department of Physiotherapy of UFSCar, allocated in individual cages with controlled conditions of temperature, light and feeding. A total of 18 male Wistar rats (Rattus norvegicus: var. Albinus, Rodentia Mammalia) weighing between 200-250g were randomly assigned to three groups. Six animals were allocated to each group:

- Group 5 (G5): animals were submitted to third-degree burns, with 5 seconds of application of the soldering iron to the tissue;

- Group 10 (G10): animals were submitted to third-degree burn, with 10 seconds of application of the soldering iron to the tissue;

- Group 15 (G15): animals submitted to 3rd degree burn, with 15 seconds of application of the soldering iron to the tissue.

\section{Experimental model of third-degree burn}

To induce burn, the animals were initially anesthetized with ketamine $(95 \mathrm{mg} /$ $\mathrm{kg}$ ) and Xylazine $(12 \mathrm{mg} / \mathrm{kg}$ ) intraperitoneally and subsequently tricotomized by the digital technique in the dorsal region (Figure 1). Subsequently, the process of burning the skin of the animal was started through a $3 \mathrm{~cm}$ diameter circular aluminum plate coupled to a soldering iron, with a total weight of 190 grams $^{8-10}$ (Figure 1), heated at a temperature of $150{ }^{\circ} \mathrm{C}$, controlled with the aid of a thermostat

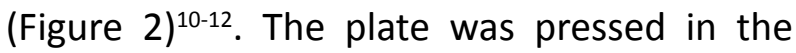
dorsal region of the animals in three different times, being for G5: 5 seconds, G10: 10 seconds and G15: 15 seconds. It is important to highlight that all burns were performed by the same evaluator and the pressure exerted on the animal's back consisted only of the appliance's own weight. 

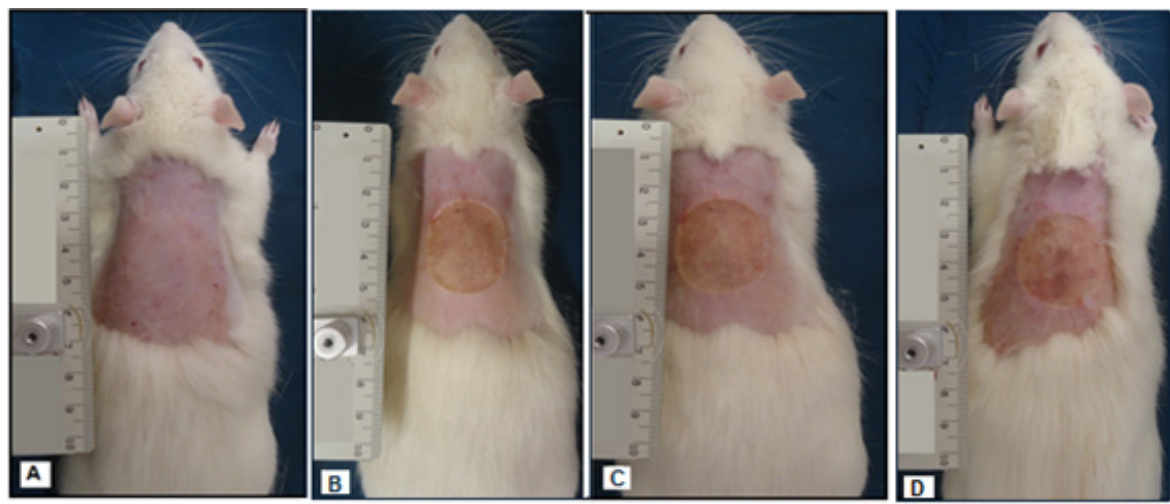

Figure 1 - A. Trichotomized animal in the dorsal region; B. Animal burned by application of soldering iron for 5 seconds; C. Animal burned by application of soldering iron for 10 seconds; D. Animal burned by application of soldering iron for 15 seconds.

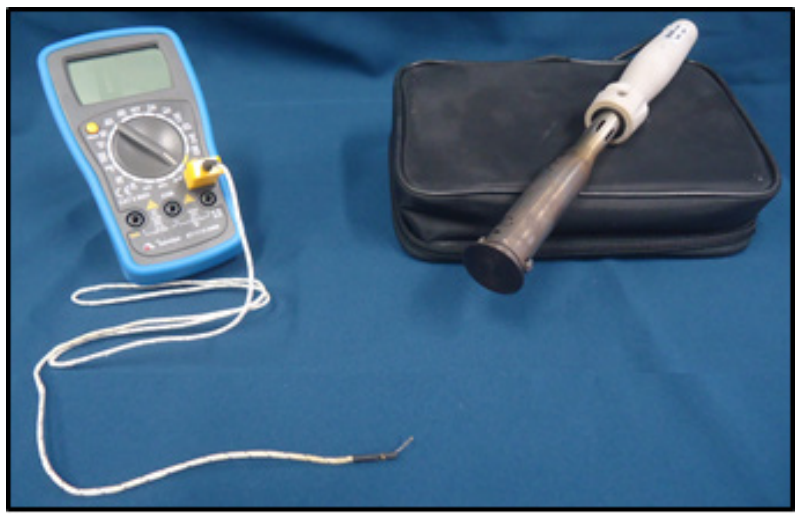

Figure 2 - Digital Multimeter Et-1110a Minipa used for temperature measurement and soldering iron equipment coupled the circular aluminum plate with $3 \mathrm{~cm}$ diameter.

\section{Histological analysis}

The euthanasia of the animals was performed with lethal dosage of anesthetic. After 30 minutes of the experimental burn model, with the animals still anesthetized, the tissues were collected for the preparation of the slides. The time of tissue collection occurred in an attempt to observe the acute pathophysiological characteristics of the lesion. The sample was collected from the tissue, standardized on the right side, containing the border region of the cutaneous lesion covering a small fragment of healthy skin and the area of the lesion itself. The samples were fixed in $10 \%$ formalin and stored in $70 \%$ alcohol, and sent for preparation and later analysis. For the preparation of the slides the samples were included in paraffin and the tissue was sectioned in $5 \mu \mathrm{m}$ thickness. The sections were stained using hematoxylin and eosin and analyzed by a blind pathologist, using a light microscope (Olympus, x100).

\section{Statistical analysis}

For analyses histopathology, the datas findings were tabulated for descriptive analysis.

\section{- Results}

Through the histopathological analyzes, it was possible to observe that no significant difference was found among the three groups studied, since all the groups had similar morphological characteristics (Figure 3), being possible to classify the three types of burns as being of third degree, with Total thickness of the tissue. 


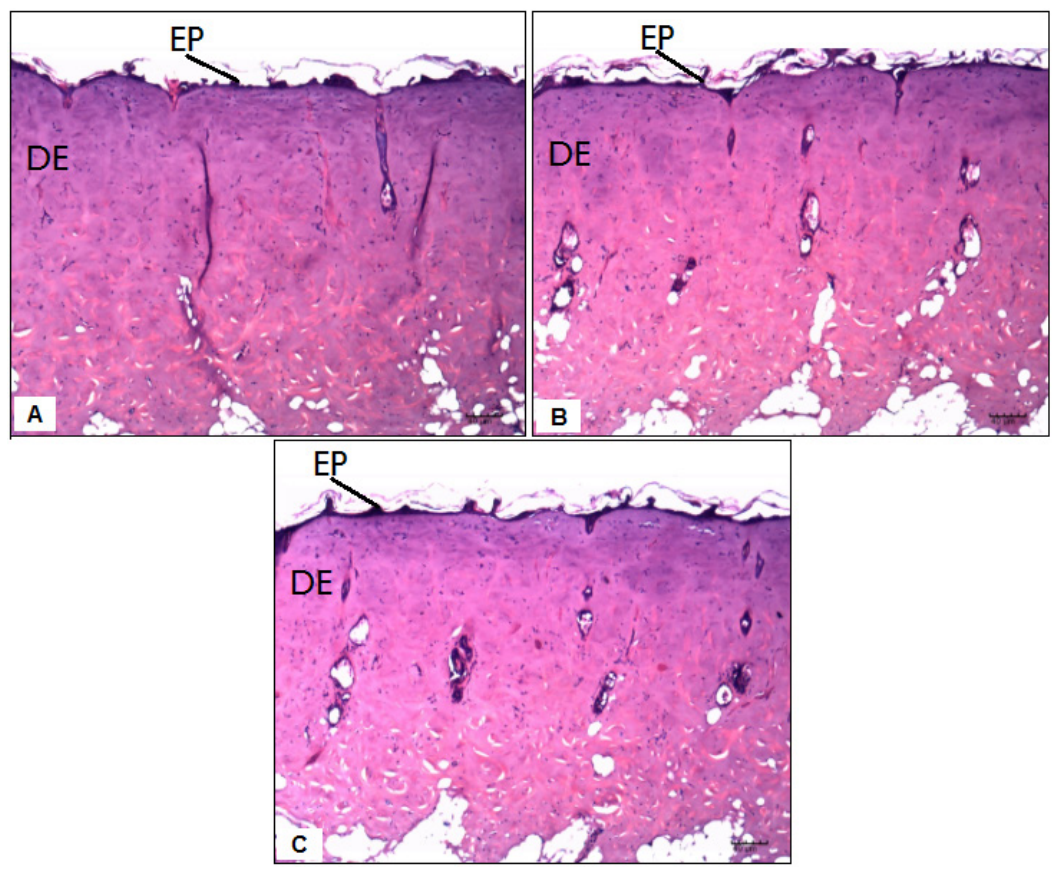

Figure 3 - Representative photomicrographs of experimental groups. A: Group 5 seconds, total necrosis of the epidermis, dermis, hypodermis with extension to muscle tissue. B: Group 10 seconds, total necrosis of the epidermis, dermis and hypodermis. C: Group 15 seconds: total epidermal necrosis, dermis, hypodermis with extension to muscle tissue.

In the $\mathrm{G} 5, \mathrm{G} 10$ and $\mathrm{G} 15$ groups it was possible to observe the total necrosis of the epidermis and its annexes, necrosis of the papillary and reticular dermis besides the vasocongestion of the deep dermis. In all three groups it was also possible to identify an extent of necrosis for the subcutaneous and muscular tissues (Table 1).

Table 1 - Presence or absence of skin and muscle structures.

\begin{tabular}{llll} 
& G5 & G10 & G15 \\
\hline $\begin{array}{l}\text { Epidermis } \\
\text { Derme }\end{array}$ & Presence & Presence & Presence \\
papilar & Presence & Presence & Presence \\
Derme Total & Presence & Presence & Presence \\
Hypodermis & Presence & Presence & Presence \\
Muscle & Presence & Presence & Presence \\
\hline
\end{tabular}

Groups: six animals in each.

\section{- Discussion}

Burns are responsible for many pathophysiological changes, which represent a severe form of trauma evolving with several complications, especially those affecting the total thickness of the skin, determined as third degree. To improve the knowledge of the pathophysiology of burn and to study possible therapeutic agents, several experimental models are highlighted in the literature in an attempt to reproduce an injury with characteristics similar to those found in clinical practice.

Among the various experimental burn models currently found in the literature are: the hot water model ${ }^{13,14}$, a model using electricity ${ }^{15}$ and the experimental model with incandescent instruments ${ }^{16-18}$. However, the first two models cited are not considered adequate procedures to produce burns, as they limit the control of the area to be burned, impairing both treatment 
and evaluations ${ }^{15}$. On the other hand, the model that uses incandescent instruments, with emphasis on the use of the model with an aluminum plate coupled to a soldering iron, proves to be a recommended method for the easy application, delimitation of the area and fixed temperature control.

Several works using aluminum coupled to the soldering iron have been presented as an effective method for the reproduction of the experimental model of third degree burns ${ }^{8,9,16-19}$, but there is a great discrepancy in the temperature used, which may vary from $100^{\circ} \mathrm{C}$ to $200^{\circ} \mathrm{C}$, in addition to the time of application that varies between 5 to 30 seconds. Caliari-Oliveira et al. ${ }^{19}$, performed a study that reproduced a third degree burn in the dorsal region of the animal, using a soldering iron with a temperature of $200 \% \mathrm{C}$ and 25 seconds of application, and the same tissue morphological characteristics were found in the study presented by KO et al. ${ }^{9}$ who also used a soldering iron to reproduce the lesion with a temperature of $200 \circ \mathrm{C}$ and a time of application of 10 seconds. Brassolatti et al. ${ }^{18}$ presented a study in which the experimental model of third degree burn was carried out through an aluminum plate coupled to a soldering iron, but the temperature used was significantly lower, being 150 ㅇ $\mathrm{C}$ with application on the back of the animal for 10 seconds, demonstrating that it is not necessary to use very high temperatures to perform this type of injury. The literature also shows lower temperatures, $100^{\circ} \mathrm{C}^{16,19}$ and $130^{\circ} \mathrm{C}$, using the model with soldering iron for the reproduction of third degree burns, but several other studies have used these temperatures with different exposure times, in order to perform ${ }^{20,21}$, thus generating disagreement regarding the morphological results that characterize the involvement of the tissue thickness.

Campelo et $a .^{7}$ discussed three different temperatures, $100^{\circ} \mathrm{C}, 150^{\circ} \mathrm{C}$ and $200^{\circ} \mathrm{C}$, for reproduction of the experimental model of burn by the direct heat transfer (heat) during 9 seconds. The results showed that the lesions generated by the temperature of 100 ㅇ $C$ did not affect the total thickness of the skin, characterized as well as the second degree, in contrast, lesions formed by the higher temperatures, presented total involvement of all layers of the skin and were then classified as third degree.

Considering the above and the data presented in our study, it was possible to verify that for the induction of a third degree lesion, in an experimental model, it is not necessary temperatures above $150^{\circ} \mathrm{C}$, as described by Busuioc $^{16}$ and Caliaria-Oliveira ${ }^{18}$. In addition, our results clearly demonstrate that there is no need to use prolonged times for induction of injury, because in only 5 seconds the desired lesion was obtained with the same morphological characteristics as those found in longer time, such as 10 and 15 seconds.

Thus, it is believed that with the two parameters highlighted by our study it is possible to establish a new protocol for the burn model, as it proved to be effective for the reproducibility of the proposed experimental model, with the use of a temperature of $150^{\circ} \mathrm{C}$ and a lower time of exposure (5 $\mathrm{min}$ ), seeking to reduce the suffering and risk of the animal.

\section{Conclusions}

The technique used is compatible for the reproduction of third degree burn in experimental model. Furthermore, it is possible emphasize that this is a safe, effective and easily reproducible method that can serve as a basis for new studies aimed at investigating new treatment approaches in third degree burns in an experimental model.

\section{References}

1. Abdullahi A, Amini-Nik S, Jeschke M. Animal models in burn research. Cell Mol Fife Sci. 
2014;71(17):3241-55. doi: 10.1007/s00018014-1612-5.

2. WHO. Global burden of disease: 2004. Geneva; 2008. Available from http:// www.who.int/healthinfo/global burden disease/GBD report 2004update full.pdf

3. Cruz BF, Cord̄ovil PBLL, Batista KN̄M. Perfil epidemiológico de pacientes que sofreram queimaduras Yes Brasil: revisão de literatura. Rev Bras Queimaduras. 2012;11(4):246.250 .

4. Brigham PA, McLoughlin E. Burn incidence and medical care use in the United States: estimates, trends, and data sources. J Burn Care Rehabil. 1996;17(2):95-107. PMID: 8675512.

5. Mitsunaga-Junior JK, Gragnani A, Ramos MLC, Ferreira LM. Rat an experimental model for burns: A systematic review. Acta Cir Bras. 2012;27(6):417-23. doi: 10.1590/ S0102-86502012000600010.

6. Atiyeh BS, Hayek SN, Gunn SW. New technologies for burn wound closure and healing review of the literature. Burns. 2005:31(8): 944-56. PMID: 16274932.

7. Campelo APBS, Campelo MWS, Britto GAC, Ayala AP, Guimarães SB, Vasconcelos PRL. An optimized animal model for partial and total skin thickness burns studies. Acta Cir Bras. 2011;26(Suppl1):38-42. doi: 10.1590/ S0102-86502011000700008.

8. Kimura $Y$, Sumiyoshi M, Kawashiro K, Sakanaka, M. Effects of ginseng saponins isolated from Red Ginseng roots on burn wound healing in mice. $\mathrm{Br} J$ Pharmacol. 2006;148(6):860-70. doi: 10.1038/ sj.bjp.0706794.

9. Ko WJ, Na YC, Suh BS, Kim HA, Heo WH, Choi GH, Lee SU. The effects of topical agent (kelo-cote or contractubex) massage on the thickness of post-burn scar tissue formed in rats. Arch Plast Surg. 2013;40(6):697-704. doi: 10.5999/aps.2013.40.6.697.

10.Venter NG, Monte-Alto-Costa A, Marques RG. A new model for the standardization of experimental burn wounds. Burns. 2015;41(3):542-7. doi: 10.1016/j. burns.2014.08.002.

11.Chiarotto GB, Neves LMG, Esquisatto MAM, Amaral MEC, Santos GMT, Mendonça FAS. Effects of laser irradiation (670-nm InGaP and $830-\mathrm{nm}$ GaAlAs) on burn of seconddegree in rats. Laser Med Sci. 2014;29:168593. doi: 10.1007/s10103-014-1573-9.
12. Yang $Y$, Zhang W, Li Y, Fang G, Zhang K. Scalded skin of rat treated by using fibrin glue combined with allogeneic bone marrow mesenchymal stem cells. Ann Dermatol. 2014;26(3):289-95. doi: 10.5021/ ad.2014.26.3.289.

13. Meireles GC, Santos JN, Chagas PO, Moura AP, Pinheiro AL. Effectiveness of laser photobiomodulation at 660 or 780 nanometers on the repair of third-degree burns in diabetic rats. Photomed Laser Surg. 2008;26(1):47-54. doi: 10.1089/ pho.2007.2051.

14. Tavares E, Trajano L, Mencalha AL. Expression of DNA repair genes in burned skin exposed to low-level red laser. Lasers Med Sci. 2014 Nov;29(6):1953-7 doi: 10.1007/s10103014-1612-6.

15.Avsar U, Halici Z, Akpinar E, Yayla $M$, Avsar U, Harun U, Harun U, Hasan Tarik A, Bayraktutan Z. The effects of argan oil in second-degree burn wound healing in rats. Ostomy Wound Manage. 2016;62(3):26-34. PMID: 26978857.

16.Mitsunaga Junior JK, Gragnani A, Ramos MLC, Ferreira, LM. Rat an experimental model for burns: a systematic review. Acta Cir Bras. 2012;27(6):417-23. PMID: 22666760.

17.Busuioc CJ, Mogosanu GD, Popescu FC, Lascar I, Parvanescu H, Mogoanta L. Phases of the cutaneous angiogenesis process in experimental third-degree skin burns: histological and immunohistochemicalstudy. Rom J Morphol Embryol. 2013;54(1):16371. PMID: 23529325.

18. Brassolatti P, Bossini PS, Oliveira MC, Kido HW, Tim CR, Almeida-Lopes L, De Avó LR, Araújo-Moreira FM, Parizotto NA. Comparative effects of two different doses of low-level laser therapy on wound healing third-degree burns in rats. Microsc Res Tech. 2016;79(4):313-20. doi: 10.1002/ jemt.22632.

19.Caliari-Oliveira C, Yaochite JN, Ramalho LN, Palma PV, Carlos D, Cunha Fde Q, De Souza DA, Frade MA, Covas DT, Malmegrim KC, Oliveira MC, Voltarelli JC. Xenogeneic mesenchymal stromal cells improve wound healing and modulate the immune response in an extensive burn model. Cell Transplant. 2016;25:201-15. doi: 10.3727/096368915X688128. 
20.Meyer TN, Silva AL. A standard burn model using rats. Acta Cir Bras. 1999;14:(4). doi: 10.1590/S0102-86501999000400009.

21.Pessolato AGT, Martins DS, Ambrósio CE, Mançanares CAF, Carvalho AF. Propolis and amnion reepithelialise second-degree burns in rats. Burns. 2011;37(7):1192-1201. doi: 10.1016/j.burns.2011.05.016.

\section{Correspondence:}

Julia Risso Parisi

Rodovia Washington Luís, s/n

13565-905 São Carlos - SP Brasil

Tel.: (55 16)3351-8985

juliaparisi@outlook.com.br

Received: June 08, 2017

Review: Aug 10, 2017

Accepted: Sept 13, 2017
Conflict of interest: none

Financial source: FAPESP
${ }^{1}$ Research performed at Physiotherapeutic Resources Laboratory, Department of Physiotherapy, Universidade Federal de São Carlos (UFSCar), Brasil. 